\title{
Experimental assembly of foraminiferal communities from coastal propagule banks
}

\author{
Susan T. Goldstein ${ }^{1, *}$, Elisabeth Alve ${ }^{2}$ \\ ${ }^{1}$ Department of Geology, University of Georgia, Athens, Georgia 30602, USA \\ ${ }^{2}$ Department of Geosciences, University of Oslo, PO Box 1047 Blindern, 0316 Oslo, Norway
}

ABSTRACT: Benthic foraminifera (protists) have long been recognized as sensitive indicators in studies on natural and human-induced environmental, paleoenvironmental, and climate change. These wideranging applications are founded on more than a century of field-based investigations in which environmental data were related to species distributions, and have subsequently been refined by the development of chemical proxies and a variety of culturebased studies. The recent discovery of foraminiferal propagule banks that occur in the fine-sediment fraction of marine depositional settings provides a novel experimental tool for examining the ecology of benthic foraminifera, their processes of dispersal, and the responses of multi-species assemblages to changing environmental conditions. In the 'propagule method' presented here, we use experimental arrays in which foraminifera are grown from propagule banks under different controlled abiotic conditions. We examined the roles of temperature, salinity, and site (exposed vs. protected) in structuring coastal assemblages and show that, because individual species respond differently, distinct assemblages grew from the same propagule bank under different environmental regimes. Temperature was the most important factor distinguishing experimental assemblages, whereas exposure of the collection site (e.g. to waves and currents, that promote or limit species dispersal to and from each site) was most important in determining species richness. The diversity of the propagule bank therefore imparts resilience to foraminiferal associations and provides a rapid-response mechanism for changing environments. This method further provides a tool for documenting changes in coastal assemblages that potentially result from warming or cooling climates.

KEY WORDS: Dispersal · Foraminifera · Propagules · Community assembly $\cdot$ Sapelo Island

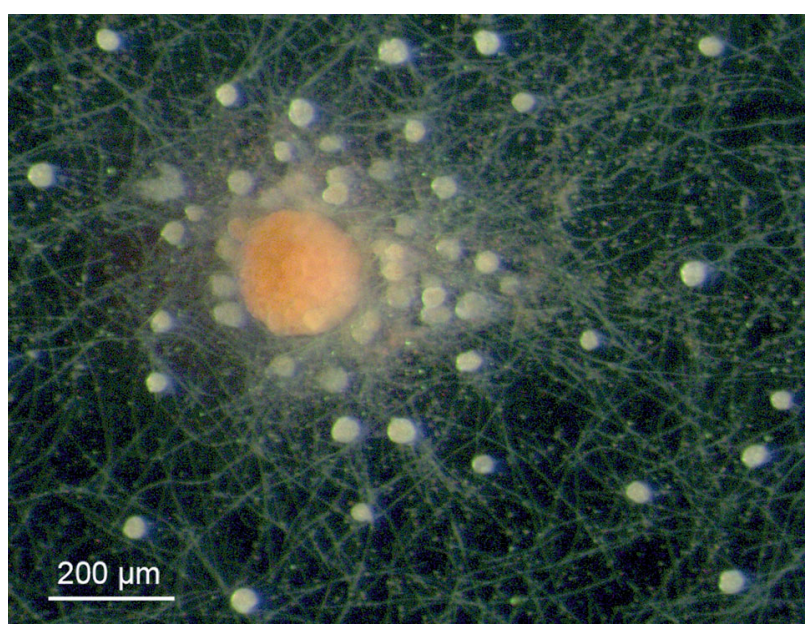

Parent and propagules (numerous small juveniles) of the foraminifer Allogromia sp. on a mat of cyanobacterial filaments.

Image: Susan T. Goldstein

\section{INTRODUCTION}

The ability of benthic foraminifera to quickly colonize new habitats and respond to changing environments hinges on their effective mechanisms of dispersal and recruitment. Benthic foraminifera disperse via several mechanisms (Alve 1999), but largely as small juveniles or propagules (Alve \& Goldstein 2002, 2003). Reproduction in benthic foraminifera typically produces 100 s of small offspring via either sexual or asexual reproduction (reviewed by Goldstein 1999) that can be passively transported by currents and ultimately deposited. The fine-sediment fraction of many depositional systems therefore contains a bank of abundant and diverse foraminiferal propagules that grow to maturity when exposed to the appropriate environmental conditions (Alve \& 
Goldstein 2003). Propagule dispersal in benthic foraminifera is broadly analogous to larval dispersal in myriad marine invertebrates that spawn, though foraminifera differ in that their dispersal is passive and their propagules can form a 'bank' of individuals. Further, propagules disperse beyond the distribution of conspecific adults, and those of some taxa may remain viable but inactive from months to several years, then subsequently grow when exposed to suitable conditions (Alve \& Goldstein 2003, 2010).

The 'propagule method' presented here is a novel experimental approach that can be used to examine the responses of some foraminifera to selected environmental parameters, as well as the effect of specific conditions on the structure of multi-species assemblages of foraminifera. In the present study, we examined the roles of temperature, salinity, and site (exposed vs. protected) in structuring communities of foraminifera from the coastal zone. To what extent does the diversity of the propagule bank permit different suites of taxa, or assemblages, to grow when exposed to different environmental conditions? Does the diversity of the propagule bank impart significant resilience to foraminiferal 'communities', and what role does it play in the assembly of foraminiferal communities in changing environments? We show that distinct assemblages develop under different conditions, and our results provide a basis for better understanding the responses of coastal foraminiferal communities to climate change.

\section{MATERIALS AND METHODS}

\section{Collection}

Surface sediments (upper few millimeters) were collected over an area of $\sim 0.5 \mathrm{~m}^{2}$ at low tide from 2 extensive mudflats on Sapelo Island, Georgia, USA (Fig. 1) on January 22, 2005. One mudflat, referred to locally as the 'Lighthouse mudflat' $\left(31^{\circ} 23.384^{\prime} \mathrm{N}\right.$, $\left.81^{\circ} 17.072^{\prime} \mathrm{W}\right)$, is an exposed site located on the southern end of the barrier island near the Sapelo lighthouse. This site is adjacent to Doboy Sound, a major tidal inlet that separates Sapelo from Sea Island and St. Simons to the south. This inlet, in turn, provides fairly direct contact with the Atlantic. The Lighthouse mudflat is bordered by a large salt marsh that includes both a broad low marsh, dominated by the halophyte Spartina alterniflora Loisel, which is typical of Georgia salt marshes, and diverse high marsh habitats (e.g. Goldstein \& Frey 1986, Goldstein \& Harben 1993). The second mudflat, here re-

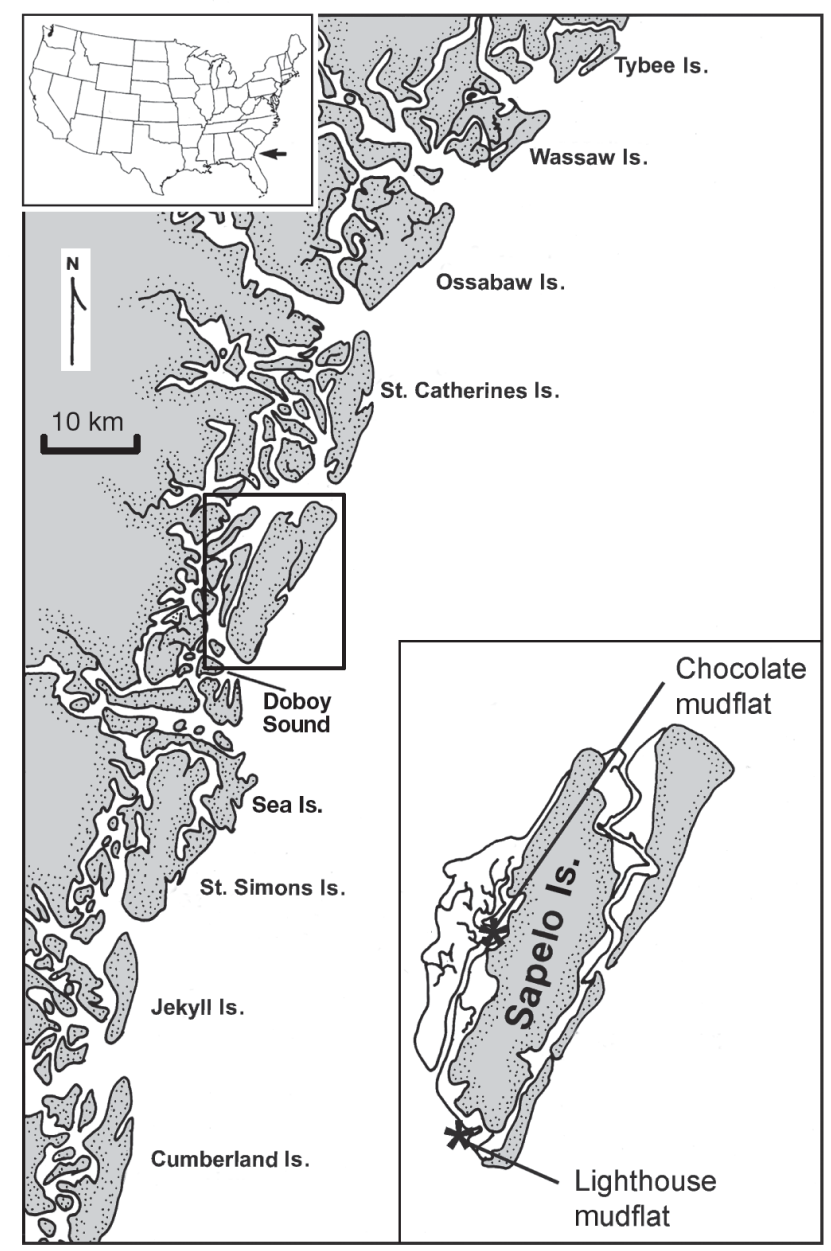

Fig. 1. Map of sampling localities on Sapelo Island, Georgia, USA. The mudflat at Chocolate is a protected backbarrier site, whereas the mudflat at the Lighthouse is an exposed site on the south end of the island

ferred to as the 'Chocolate mudflat' $\left(31^{\circ} 30.166^{\prime} \mathrm{N}\right.$, $81^{\circ} 15.293^{\prime} \mathrm{W}$ ), is located in the tidal estuary of the Mud River, and is adjacent to the historical site on Sapelo Island known as Chocolate. The Mud River, as part of the Sapelo Sound system, is one of many tidal rivers along the Georgia coast (Howard \& Frey 1985), and, although deemed a 'river', the flow is tidal and the system lacks input from any major freshwater system. This is a backbarrier site with only indirect connection to the Atlantic. The Chocolate mudflat is bordered by a narrow salt marsh located on a relatively steep gradient. The low marsh is not well developed at this site, and the high marsh consists primarily of a narrow stand of the halophyte Juncus roemerianus Scheele.

Mudflats at both the Lighthouse and Chocolate sites are extensive and associated with large oyster bioherms. When exposed at low tide, prominent 
patches of diatoms are apparent on the sediment surface, particularly during the summer months, and abundant ostracodes and mud snails Ilyanassa obsoleta Say are also present. Sediments at both sites are very loosely consolidated, soupy, and become black and sulfide-rich just a few millimeters below the surface. Both collecting sites are brackish, and the salinity, which can vary considerably throughout the year, measured 22 (with a refractometer) at both sites at the time of collection. The Georgia Coastal Ecosystems Long-Term Ecological Research program collects environmental data, including temperature and salinity, at a number of sites in the Sapelo Island area. Those monitoring sites closest (within $2 \mathrm{~km}$ ) to our sampling sites used in the present study recorded daily mean temperatures and salinities of $\sim 8$ to $30^{\circ} \mathrm{C}$ and $\sim 10$ to 30 , respectively, near the Lighthouse mudflat, and $\sim 6$ to $31^{\circ} \mathrm{C}$ and $\sim 9$ to 28 near the mudflat at Chocolate (see http://gce-lter.marsci.uga.edu). Environmental conditions on the adjacent continental shelf, located within the Mid-Atlantic Bight, also vary throughout the year. At depths between 10 and $200 \mathrm{~m}$, temperatures and salinities are $\sim 8$ to $23^{\circ} \mathrm{C}$ and $\sim 27$ to 36 , respectively (see http:// edac-dap2.northerngulfinstitute.org/erddap/griddap/ NCOM_mid_atlantic_bight_3d_agg.html).

After collection, sediments were transported to the University of Georgia Marine Institute on Sapelo Island where they were sieved using 850 and $53 \mu \mathrm{m}$ stainless-steel sieves. The coarser sieve was used to remove larger metazoans and detritus. Material retained on the $53 \mu \mathrm{m}$ sieve was fixed in $4 \%$ paraformaldehyde (buffered with sodium carbonate to $\mathrm{pH}>8$ ) in artificial seawater (salinity 35 ; Instant Ocean, Aquarium Systems) with $0.1 \%$ rose Bengal and used to determine the species content of the in situ foraminiferal assemblages at each site. This $>53 \mu \mathrm{m}$ fraction was re-sieved using a $63 \mu \mathrm{m}$ sieve, split to obtain a workable volume $(1 / 32$ of the original), and preserved in $70 \%$ ethanol. The sample was rinsed in tap water, and foraminifera were picked wet, identified, and tallied.

Sediment that passed through the $53 \mu \mathrm{m}$ sieve was retained in large plastic containers (1 for each site), sealed, refrigerated, transported to the University of Georgia campus in Athens, Georgia, and used for the subsequent propagule experiments, which were started on January 27 and 30, 2005, for the Chocolate and Lighthouse mudflats, respectively. The $<53 \mu \mathrm{m}$ fraction was selected based on previous results (Alve \& Goldstein 2003). It excludes fully grown individuals of most foraminiferal species, but includes small juveniles including those with a relatively large proloculus (first chamber).

\section{Experimental design}

The fine-sediment fraction $(<53 \mu \mathrm{m})$ from each site was thoroughly mixed, and $20 \mathrm{ml}$ aliquots were extracted with a large pipette, measured with a graduated cylinder, and placed in a series of small, translucent containers (polypropylene; round, $118 \mathrm{ml}$ ) with tightly fitting lids, along with $40 \mathrm{ml}$ of Instant Ocean. Containers were further sealed with parafilm (not opened over the course of the experiment) and illuminated with artificial, broad-spectrum lighting set on a $12 \mathrm{~h}$ cycle to promote algal growth in the containers. For the present study, we used 2 constant temperatures $\left(12^{\circ} \mathrm{C}\right.$ and room temperature, $\left.\mathrm{RT}, \sim 22^{\circ} \mathrm{C}\right)$ and 3 salinity treatments. The concentration of Instant Ocean was adjusted to yield final salinities of 12,22 (=ambient), or 36. These experimental temperatures and salinities were chosen to reflect a range of those that occur naturally at the collecting sites and on the nearby continental shelf.

Each treatment had a replicate, yielding 24 containers $(2$ sampling sites $\times 2$ temperatures $\times 3$ salinities $\times 2$; Fig. 2), which were harvested after 6 wk. A second identical set of 24 samples was harvested after 12 wk. The 12 wk dataset, however, includes only the 12
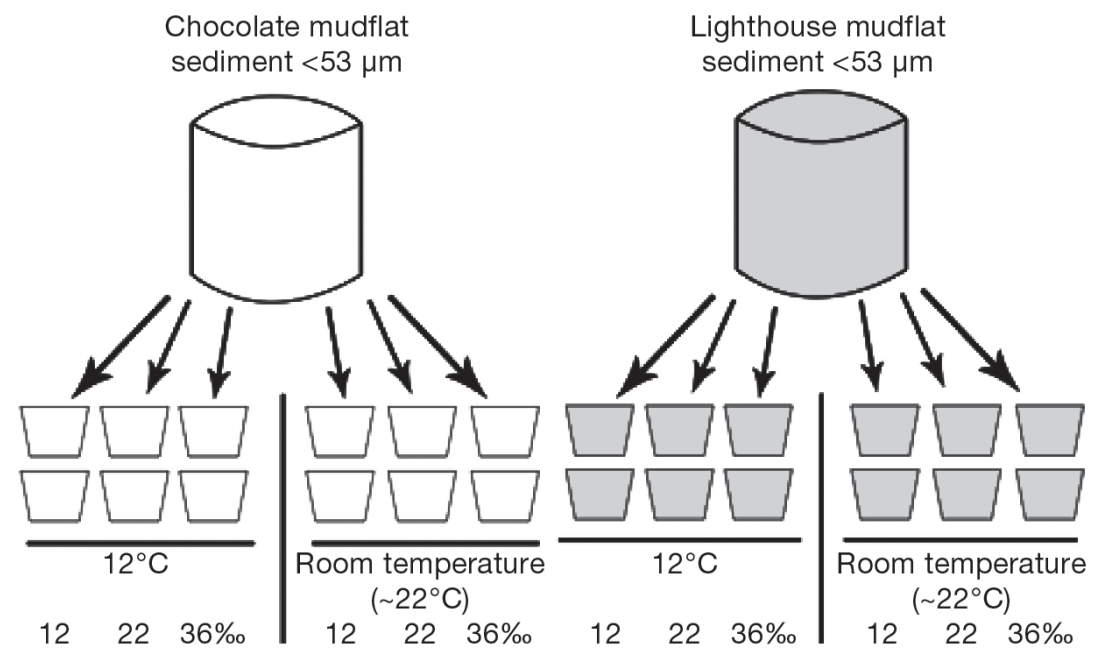

Fig. 2. Outline of the experimental design. See 'Materials and methods: Experimental design' for description 
samples derived from the Lighthouse sampling site. Those from the Chocolate mudflat site were damaged after harvesting and could not be examined.

Samples were harvested by sieving over a $63 \mu \mathrm{m}$ stainless steel sieve using artificial seawater (Instant Ocean). The $63 \mu \mathrm{m}$ sieve is the size most commonly employed in micropaleontological analyses for foraminifera and was therefore selected for the present study. In order to be retained on this sieve, foraminiferal propagules present in the initial finesediment fraction would have grown by at least $10 \mu \mathrm{m}$. The material retained on the $63 \mu \mathrm{m}$ sieve was fixed for 5 to $7 \mathrm{~d}$ in an Instant Ocean mixture that contained buffered $4 \%$ paraformaldehyde. Samples were then rinsed in tap water and stored in $70 \%$ ethanol. Samples were returned to tap water, picked wet, identified and counted. All harvested foraminifera were included in the tallies whether they were alive or not at the conclusion of the experiment because all had grown (at least $10 \mu \mathrm{m}$ ) during the study.

\section{Data analysis}

The relationship between assemblage characteristics (abundance and species richness) and salinity, temperature, and sampling site was tested using analysis of variance (ANOVA) (Systat Ver. 13; Systat Software). Cluster analysis, non-metric multi-dimensional scaling (MDS), and species diversity (species richness and Fisher's alpha; Fisher et al. 1943) calculations were performed using Primer Ver. 6.1.6 (Clarke \& Gorley 2006). For all analyses, the absolute abundance values of pooled (added) replicates were used, unless otherwise stated. The MDS technique plots samples in 2-dimensional space 'such that the relative distances apart of all points are in the same rank order as the relative dissimilarities (or distances) of the samples, as measured by some appropriate resemblance matrix calculated on the (possibly transformed) data matrix' (Clarke \& Gorley 2006, p. 75). For cluster analyses and MDS the 'faunal' data were square-root transformed and resemblances calculated using the Bray-Curtis method (Bray \& Curtis 1957). To assess the significance of the effect of temperature, salinity, and site on the delineation of assemblage groupings, we performed an analysis of similarity (ANOSIM), also using a square-root transformation of the abundance data and Bray-Curtis resemblances. Results from the cluster analysis as well as species abundance patterns were overlain on the MDS plots using Primer Ver. 6.1.6.

\section{RESULTS}

\section{In situ assemblages of foraminifera}

The assemblages of foraminifera (individuals $>63 \mu \mathrm{m})$ that were alive on the mudflats at each site at the time of collection (January 2005) have a similarity of $92 \%$ (Table $\mathrm{S} 1$ in the supplement at www.int-res.com/articles/suppl/m437p001_supp.pdf). Both assemblages were strongly dominated by Haynesina germanica (Ehrenberg), as were the assemblages that subsequently grew in the various treatments (see following subsection). Other common species living on these mudflats included Elphidium excavatum (Terquen), Ammonia tepida (Cushman) (=Ammonia 'T7' of Hayward et al. 2004), Psammophaga sp., and Ovammina opaca Dahlgren (Fig. 3). Of these, H. germanica, E. excavatum, and A. tepida are all rotaliids and have calcareous perforate tests. Psammophaga sp. and O. opaca are monothalamid foraminifera with flexible, agglutinated tests. These 5 most common species accounted for 97 and $95 \%$ of the in situ living assemblages at the Chocolate and Lighthouse mudflats sites, respectively. In addition, Miliammina fusca (Brady) and Ammotium salsum (Cushman \& Brönnimann) were also present though not abundant $(\leq 1 \%)$ in the living assemblages at the time of sampling.

The primary difference between the in situ assemblages at these 2 mudflat sites was that the dead assemblage (consists of empty tests) at the Light-

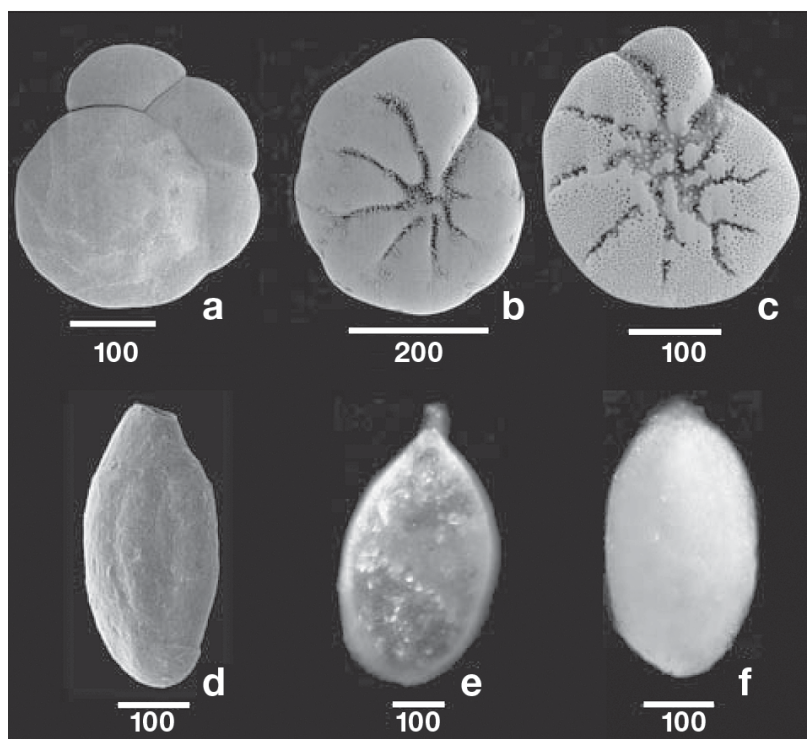

Fig. 3. The 6 species of foraminifera most commonly encountered: (a) Ammonia tepida, (b) Haynesina germanica, (c) Elphidium excavatum, (d) Miliammina fusca, (e) Psammophaga sp., and (f) Ovammina opaca. All scale bars are in $\mu \mathrm{m}$ 
house site was more diverse and included a number of species that are more typical of the adjacent low marsh environments than mudflats (e.g. Trochammina spp., Arenoparrella mexicana [Kronfeld]), or the open waters of the continental shelf, sound, or beyond (e.g. Globigerina bulloides [d'Orbigny], Wiesnerella auriculata [Egger], Guttulina laceata [Walker \& Jacob]) (e.g. Sen Gupta \& Kilbourne 1976, Goldstein \& Harben 1993). Overall, species richness, particularly of the dead assemblage, was higher at the exposed Lighthouse site ( 27 species of which 10 were alive) than at the protected mudflat at Chocolate (14 species of which 10 were alive). This pattern is also reflected in Fisher's alpha index where the assemblage from the Lighthouse mudflat consistently had higher values (Lighthouse: living assemblage $=2.2$, dead assemblage $=8.3$; Chocolate: living assemblage $=2.0$, dead assemblage $=3.5$ ).

\section{Experimentally grown assemblages}

At the conclusion of the experiment (6 or $12 \mathrm{wk}$ ), the containers showed no evidence of anoxia or fouling, and diatoms were recorded on both the sediment surface and on the sides of the containers. The sediment surface in all containers had a 'granular' appearance, which is a typical indication of foraminiferal activity in restricted fine-grained sediments. Individual benthic foraminifera commonly collect sediment and the associated microbiota around them, thus forming loosely constructed feeding cysts (e.g. Goldstein \& Corliss 1994). Such cysts, whether for feeding, reproduction, morphogenesis, or other functions (Heinz et al. 2005), were common over the sediment surface in the containers. In addition, all containers yielded numerous foraminifera (see next paragraph), which further indicates the lack of fouling over the course of the experiment.

After 6 wk, individual containers, each of which contained $20 \mathrm{ml}$ of the original fine-sediment fraction $(<53 \mu \mathrm{m})$, were harvested by sieving and yielded from 323 to 1325 foraminifera $>63 \mu \mathrm{m}$ (Table S2 in the supplement at www.int-res.com/ articles/suppl/m437p001_supp.pdf). Those assemblages grown over a $12 \mathrm{wk}$ period yielded from 514 to 1246 foraminifera >63 $\mu \mathrm{m}$ (Table S3 in the supplement). These tallies include all foraminifera $>63 \mu \mathrm{m}$ in size that were present at the conclusion of the experiment, regardless of whether they were alive or dead, since all of these individuals were alive and growing (by at least $10 \mu \mathrm{m}$ ) over the course of the experiment.
Foraminiferal abundances varied greatly among treatments (i.e. the individual containers harvested). Those individual assemblages grown at the lowest salinity (12) yielded significantly fewer individuals (average $=516$ ) than those grown at the higher salinities (average $=872$ ind. grown at $22 \%$ and 763 ind. at $36 \%$; ANOVA F-ratio $=18.805$ and 9.773, p $<0.001$ and $p=0.005$, respectively), whereas those grown at salinities of 22 and 36 yielded abundances that were not significantly different $(F$-ratio $=1.030, \mathrm{p}=0.321$ ). With regard to site, the propagule bank from the Lighthouse mudflat overall yielded abundances that were just slightly higher than those from the Chocolate mudflat $(F$-ratio $=2.667, \mathrm{p}=0.112)$. Abundance values were comparable for assemblages grown at different temperatures $(F$-ratio $=0.000, \mathrm{p}=0.994)$ (Fig. 4).

Species richness ranged from 7 to 21 species in individual containers harvested after $6 \mathrm{wk}$ and from 7 to 20 species in those grown for $12 \mathrm{wk}$. These species included calcareous, agglutinated, and organicwalled taxa. Site proved to be the only factor with a significant relationship to species richness (ANOVA: $F$-ratio $=15.816, p=0.001)$. Assemblages grown from sediment collected at the exposed site (Lighthouse mudflat) collectively yielded greater species richness (49 species total) than those grown from the protected site at Chocolate (35 species total) (Fig. 5, Tables S2 \& S3). The highest species richness occurred in treatments grown at the highest salinities (Fig. 5, Tables S2 \& S3), but no significant correlation between species richness and either salinity or temperature was found (ANOVA: salinity, F-ratio $=$ $0.751, \mathrm{p}=0.489$; temperature, $F$-ratio $=1.588, \mathrm{p}=$ 0.226 ). Fisher's alpha ranged from 1.1 to 2.9 (average $=1.7)$ for the 12 Chocolate samples and from 1.1 to 4.5 (average $=2.5$ ) for the 24 Lighthouse samples.

The cluster and MDS analyses defined 2 main groups of assemblages distinguished by temperature: one group includes all assemblages grown at $\mathrm{RT}$ and the other includes those grown at $12^{\circ} \mathrm{C}$ (Fig. 6; ANOSIM, R = 0.839, $\mathrm{p}=0.001$ ). Within each of these groups, higher salinity treatments (22 and 36) grouped together, whereas those assemblages grown at the lowest salinity (12) grouped separately. The role of salinity, therefore, was not statistically significant (ANOSIM, R $=0.129, \mathrm{p}=0.094$ ) than that of temperature. Overall, the greatest similarity existed among assemblages grown under the same temperature and salinity conditions, regardless of the source of propagules (i.e. site; ANOSIM, R $=0.081$, $\mathrm{p}=0.186$ ) or duration of the experiment $(6$ or $12 \mathrm{wk})$. 

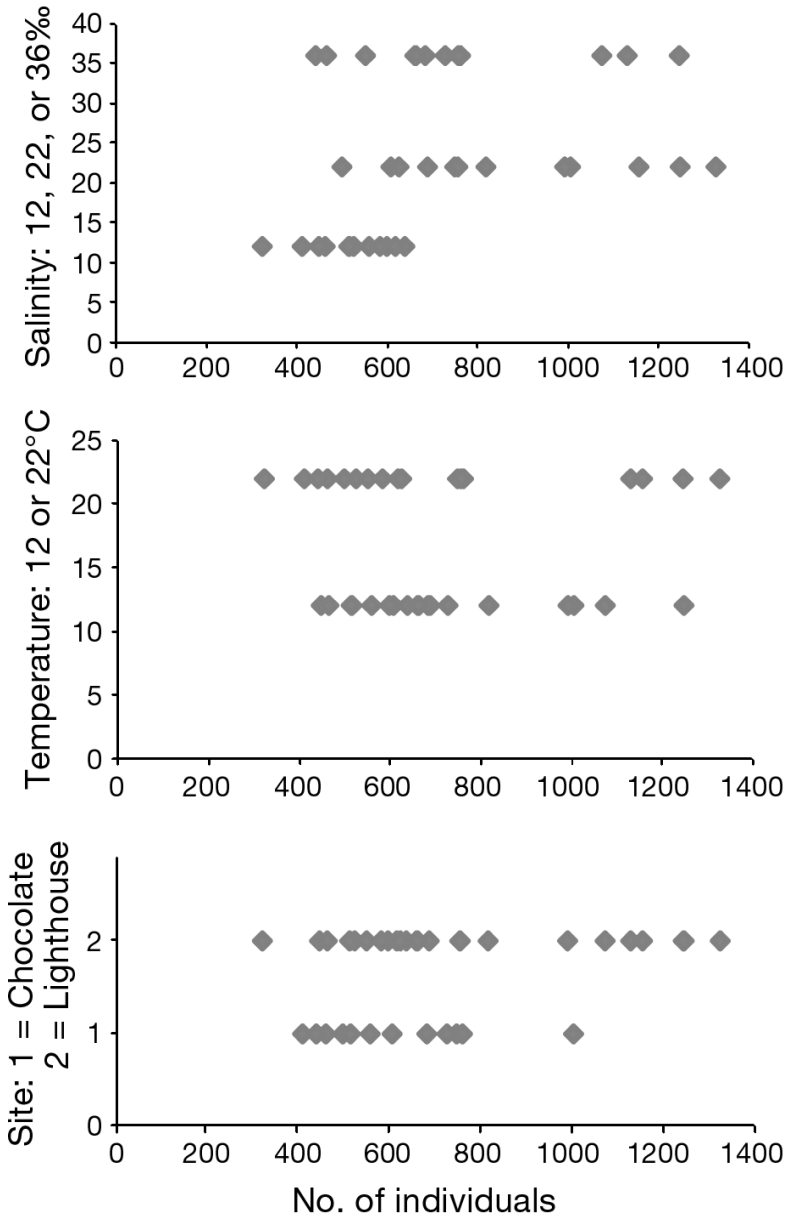

Fig. 4. Abundance of foraminifera $>63 \mu \mathrm{m}$ grown under different experimental conditions for 6 or $12 \mathrm{wk}$ from propagules in $20 \mathrm{ml}$ of sediment plotted against salinity $(12,22$, or $36)$, temperature $\left(12^{\circ} \mathrm{C}\right.$ or room temperature $\left.\left[\sim 22^{\circ} \mathrm{C}\right]\right)$, and sampling site (mudflats at either Chocolate or the Lighthouse on Sapelo Island, Georgia, USA)

The distinction of assemblages grown under different temperature and salinity conditions reflects the different species responses to these conditions (Fig. 7). Overall, 6 species grew abundantly in multiple experimental treatments: Haynesina germanica, Psammophaga sp., Ammonia tepida, Elphidium excavatum, Ovammina opaca, and Miliammina fusca (Tables S2 \& S3); all of these were also wellrepresented in the in situ assemblages. No 'exotic' (i.e. allochthonous) taxa were among these 6 most abundant ones, although several did grow over the course of the experiment (see end of this section).

Of these 6 dominant taxa, Haynesina germanica was by far the most common, as it was in the in situ assemblages from both collecting sites (Fig. 7a). It grew in all of the containers, reached a maximum abundance of 789 ind. per $20 \mathrm{ml}$ sediment, and com-
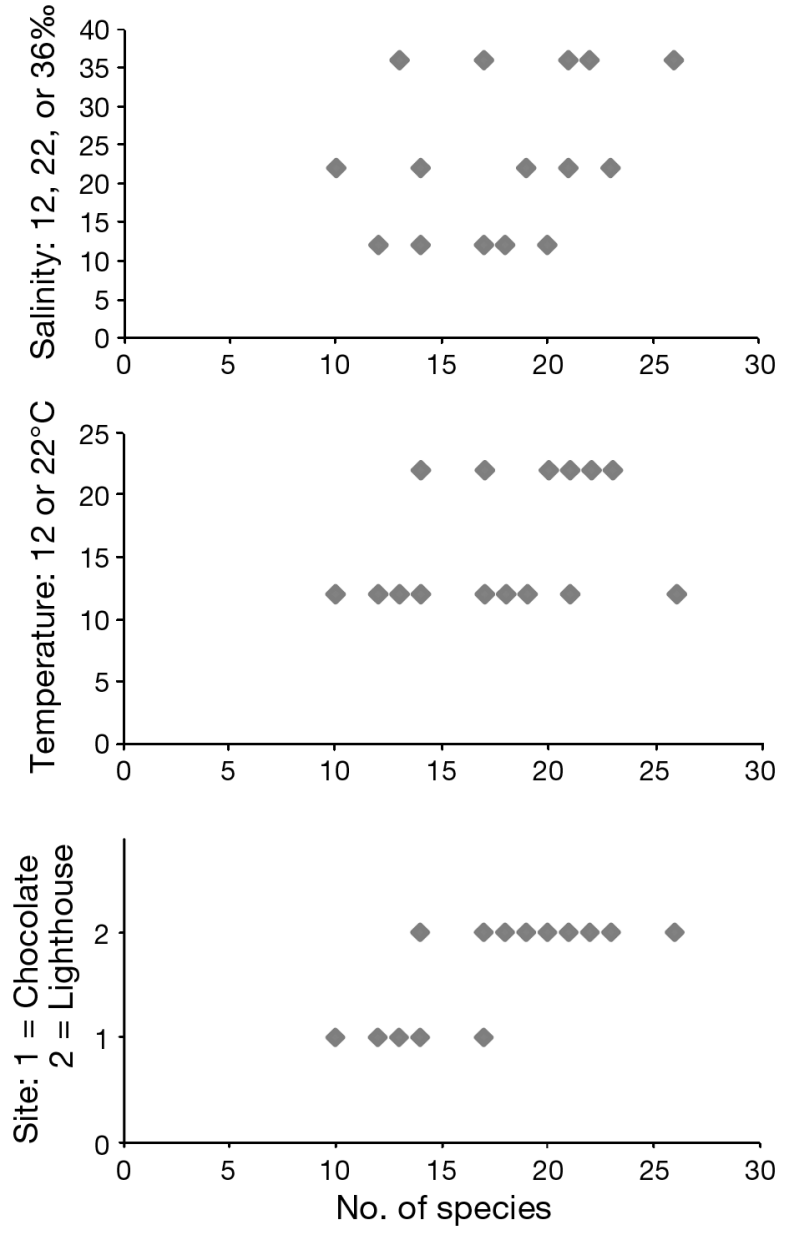

Fig. 5. Number of species in assemblages grown from $20 \mathrm{ml}$ sediment under different experimental conditions for 6 and 12 wk plotted against salinity $(12,22$, or 36$)$, temperature $\left(12^{\circ} \mathrm{C}\right.$ or room temperature $\left.\left[\sim 22^{\circ} \mathrm{C}\right]\right)$, and sampling site (mudflats at either Chocolate or the Lighthouse on Sapelo Island, Georgia, USA)

prised 5 to $81 \%$ of the individual experimental assemblages grown for $6 \mathrm{wk}$ and 32 to $88 \%$ of those grown for $12 \mathrm{wk}$. It was the dominant (most abundant) foraminiferan in 19 of the 24 assemblages that grew for $6 \mathrm{wk}$ and in all of those grown for $12 \mathrm{wk}$. Both adults and juveniles were recovered at the end of the experiment (both 6 and 12 wk durations). $H$. germanica grew abundantly at both experimental temperatures and at all salinities, but the highest number of individuals occurred in the $12^{\circ} \mathrm{C}$ treatments.

Psammophaga sp. likewise grew abundantly (max. 442 ind. $20 \mathrm{ml}^{-1}$ sediment) at both experimental temperatures and at all salinities, though it was less abundant at the lowest salinity (12) (Fig. 7b). This species comprised 1 to $43 \%$ of assemblages grown for $6 \mathrm{wk}$ and 0 to $26 \%$ of those grown for $12 \mathrm{wk}$. In many cases, 


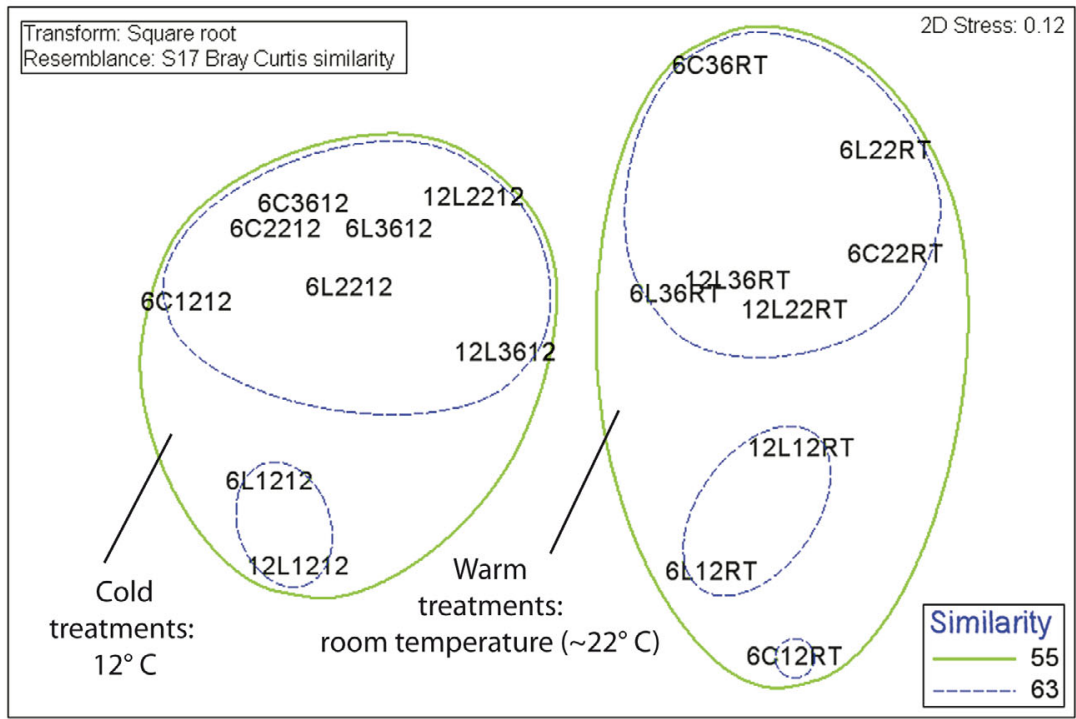

Fig. 6. Multi-dimensional scaling ordination of the sum of replicates from all treatments (both 6 and 12 wk experiments). Results of cluster analyses using 55 and 63 as threshold levels of similarity are superimposed (contour lines encircle the clusters they define). Treatment abbreviations code for duration (6 or $12 \mathrm{wk}$ ), site $(\mathrm{C}=$ Chocolate, $\mathrm{L}=$ Lighthouse), salinity $(12,22$ or 36$)$ and temperature $\left(12^{\circ} \mathrm{C}\right.$ or room temperature $\left.\left[\mathrm{RT}, \sim 22^{\circ} \mathrm{C}\right]\right)$
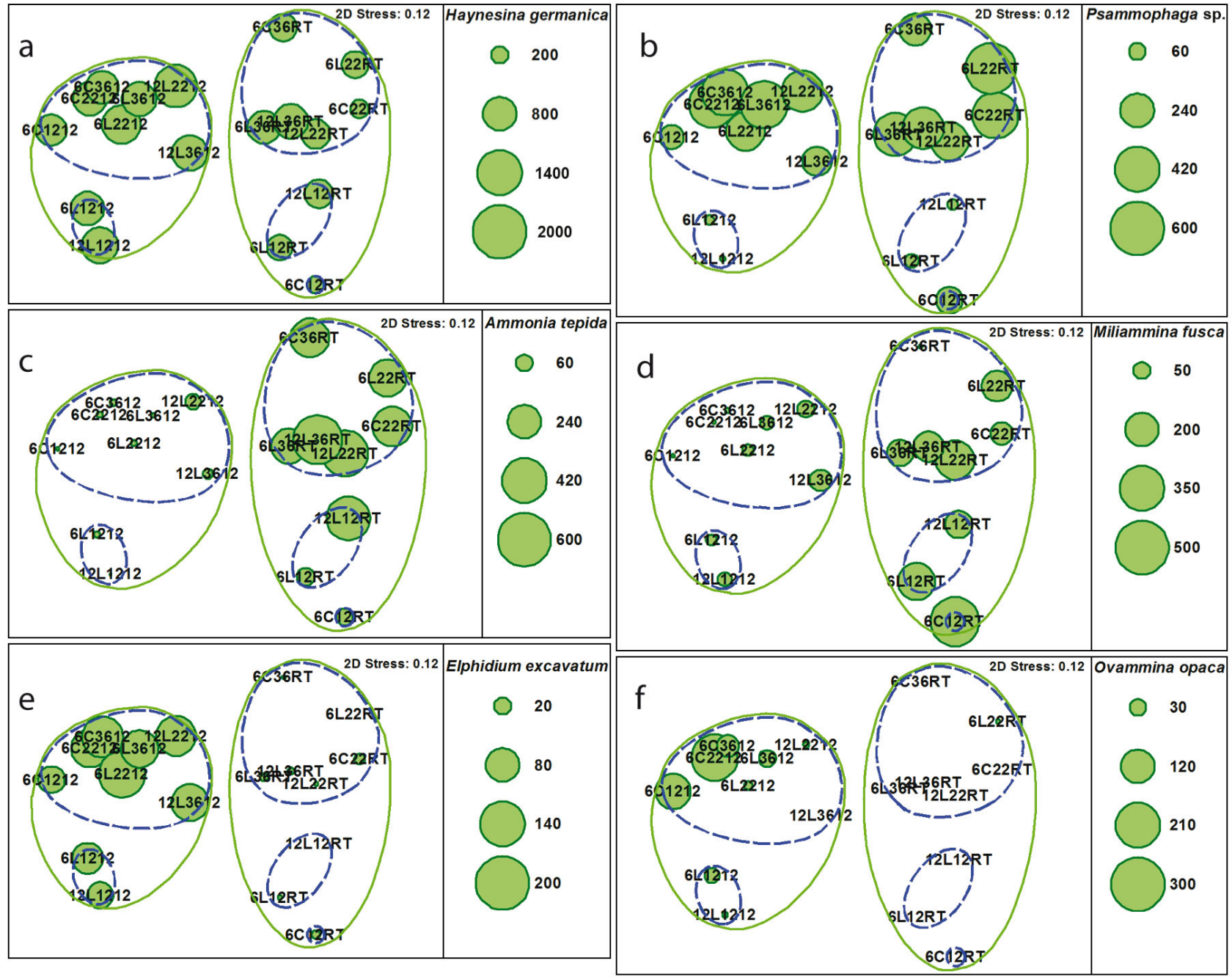

Fig. 7. Abundances of the 6 most common species grown in experimental treatments (replicates pooled; individuals per $40 \mathrm{ml}$ of original sediment) overlain on the multi-dimensional scaling plot from Fig. 6. Note that the scale (bubbles) varies. (a) Haynesina germanica, (b) Psammophaga sp., (c) Ammonia tepida, (d) Miliammina fusca, (e) Elphidium excavatum, (f) Ovammina opaca 
it was more abundant in the experimental treatments than at either of the collecting sites where it comprised just $7 \%$ of the living assemblage at the Lighthouse mudflat and $15 \%$ at the Chocolate mudflat.

Ammonia tepida grew abundantly (max. 348 ind. $20 \mathrm{ml}^{-1}$ ) at the warmer temperature (RT) (Fig. 7c). It also grew at all salinities, but generally had higher abundances at higher salinities (22 and 36). This species comprised 5 to $43 \%$ of the 6 wk assemblages grown at RT and 16 to $49 \%$ of those grown for $12 \mathrm{wk}$ at this temperature. A. tepida was nearly absent (0 to $4 \%$ ) in assemblages grown at $12^{\circ} \mathrm{C}$ regardless of the duration. The in situ assemblages at the Chocolate and Lighthouse mudflats included 8 and $3 \%$ of $A$. tepida, respectively.

Miliammina fusca likewise grew in the warmer temperature treatments (Fig. 7d). This species grew at all salinities, but was more abundant (max. 225 ind. $20 \mathrm{ml}^{-1}$ ) in the low salinity (12) treatments. M. fusca constituted 0 to $65 \%$ of the warm-water treatments grown for 6 wk and 5 to $33 \%$ of those grown for 12 wk. This species was nearly absent (0 to $3 \%$ ) in the cold-water assemblages grown for $6 \mathrm{wk}$, but was somewhat more abundant ( 2 to $8 \%$ ) in those coldwater assemblages grown for $12 \mathrm{wk}$.

Elphidium excavatum grew almost exclusively in the lower temperature $\left(12^{\circ} \mathrm{C}\right)$ treatments but at all salinities combined with this temperature (Fig. 7e). This species showed a maximum abundance of 81 ind. $20 \mathrm{ml}^{-1}$ sediment and comprised 4 to $10 \%$ of individual assemblages grown at $12^{\circ} \mathrm{C}$ for $6 \mathrm{wk}$ and 4 to $11 \%$ of those grown for $12 \mathrm{wk}$ at this temperature. It made up only 0 to $1 \%$ of those assemblages grown at $\mathrm{RT}$ regardless of duration. E. excavatum was more abundant in the in situ assemblages (collected during the winter) at both collecting sites, where it constituted $18 \%$ at the Chocolate and $22 \%$ at Lighthouse mudflat.

Ovammina opaca likewise grew in the lower temperature treatments, but had its highest abundances (max. 165 ind. $20 \mathrm{ml}^{-1}$ ) at lower salinities (12 and 22) (Fig. 7f). This species comprised 0 to $27 \%$ of the assemblages grown at the lower temperature for $6 \mathrm{wk}$. It was absent in all assemblages grown at RT. It was nearly absent (0 to 3 individuals per assemblage) from all of the assemblages grown for 12 wk regardless of temperature or salinity. O. opaca accounted for $\sim 5 \%$ of the in situ assemblages at both collecting sites, however, it grew more abundantly from sediments collected at the Chocolate mudflat.

In addition, several species that are more typical of subtidal habitats of the continental shelf or sound (Sen Gupta \& Kilbourne 1976) grew abundantly in one to several containers. These include Textularia candeiana d'Orbigny, Fissurina lucida (Williamson), and Buliminella elegantissima (d'Orbigny).

\section{DISCUSSION}

The bank of propagules (tiny juveniles) present in the fine-grained sediment fraction of depositional systems provides a novel tool for experimental ecological studies on foraminifera. The propagule bank can be manipulated experimentally to examine the role of selected environmental parameters on the assembly of foraminiferal communities, as well as the individual species responses to particular conditions. Here we have demonstrated that distinct assemblages can be grown from the same propagule bank by applying different combinations of environmental conditions. Further, the taxonomic makeup of these assemblages hinges on the different responses of individual species present in the propagule bank.

Past and current experimental approaches in studies on foraminiferal ecology (e.g. Talge \& Hallock 2003, Pascal et al. 2008, Mojtahid et al. 2011) generally use either adults of relatively large species, which are easy to isolate and manipulate, or complete assemblages in their original sediment which are transferred from field to experimental conditions (microcosms). Separating individuals which have grown and/or reproduced from those which have not during the course of the experiment is commonly time-consuming, a logistical challenge, and may introduce errors. Here we rely instead on juveniles that grow to maturity during the experiment, thus ensuring that these individuals respond positively to the treatment. This approach has the further advantage of focusing on critical developmental stages (Olsgard 1999) while also being logistically simple.

Foraminifera grew abundantly in all treatments, and abundances varied both among treatments and between replicates. The most important factor accounting for abundance variation among treatments is reduced salinity (lowest at $12 \%$ ). The abundance variation between replicates of the same treatment most likely reflects slight variations in reproduction. In general, a single foraminiferan can produce from several to $>100$ offspring (e.g. Jepps 1942, Arnold 1955). Slight variations in the number of individuals undergoing reproduction, therefore, can result in large differences in assemblage abundances. In addition, the abundances of monothalamid species, particularly Ovammina opaca, were lower in assemblages grown for $12 \mathrm{wk}$ rather than $6 \mathrm{wk}$. This may 
reflect the inability of these species to reproduce effectively coupled with the post-mortem degradation of the test (e.g. Goldstein \& Barker 1988).

Those species that grew most prolifically in the experimentally grown assemblages are those that were present on the mudflats at the time of collection. This suggests that most of these propagules were derived from local or in situ populations. Several exotic or allochthonous species grew in some treatments, but in relatively small numbers. Though capable of growing, these were not able to out-compete the resident taxa or otherwise become dominant under any of the experimental conditions employed. Their presence, particularly in assemblages grown from the exposed site, illustrates the influence of a direct physical connection to a larger regional species pool (Buzas \& Culver 1994, Leibold et al. 2004).

The growth of distinct assemblages of foraminifera from the same propagule bank under different conditions demonstrates that multiple, alternative assemblage structures are possible. The diversity of the propagule bank, therefore, provides a mechanism for rapid responses to changing conditions and imparts resilience for these assemblages. The distinct foraminiferal assemblages identified by cluster and MDS analyses are delimited first by temperature and secondarily by salinity, thus demonstrating the importance of these niche-related factors. The greatest influence on species richness, however, was the location of the sampling site. Higher species richness occurred in assemblages grown from the propagule bank collected at the exposed site (Lighthouse) rather than the protected, backbarrier site (Chocolate). This trend is also reflected in the species richness of the in situ dead assemblages at these 2 sites. Overall, this suggests that dispersal to the protected, backbarrier site is more limited and that dispersal limitation also plays a role in structuring foraminiferal associations.

We know very little about the trophic interactions of most foraminifera and the potential roles of competition and predation in structuring foraminiferal 'communities.' Those species that grew in the experimental treatments utilize a range of nutritional resources with some degree of overlap and potential for competition. Two species use organelle retention: Haynesina germanica (Lopez 1979, Knight \& Mantoura 1985, Austin et al. 2005) and Elphidium excavatum (Correia \& Lee 2000), both sequester diatom chloroplasts. In addition, $H$. germanica may graze on bacteria (Mojtahid et al. 2011). Psammophaga sp., characterized by its avid ingestion of silt-sized sediment, is most likely a deposit feeder. Ammonia tepida utilizes micro-algal grazing, bacterial grazing, and deposit feeding (Goldstein \& Corliss 1994, Pascal et al. 2008), but it is also a carnivore (Dupuy et al. 2010). This species appears to have the most diverse diet of those present and is the only known carnivore in any of the assemblages. Ovammina opaca also feeds on diatoms and other forms of micro-algae (S. T. Goldstein unpubl. data), whereas the diet of Miliammina fusca remains undocumented. The potential for competition among these common species exists, given both the overlap in diet and the limited space available in the growth chambers. However, if food remained abundant over the course of the experiment, then competition may have remained minimal.

Food was probably plentiful in all experimental treatments. The initial $20 \mathrm{ml}$ aliquot of fine-grained sediment included both foraminiferal propagules and an associated microbiota. All assemblages were grown with exposure to light $12 \mathrm{~h} \mathrm{~d}^{-1}$, and diatoms, for example, commonly grew on both the sediment surface and the sides of the containers. Initially, the food available in the treatments was probably comparable to that of the in situ habitats. The extent to which potential food organisms (micro-algae, bacteria) may have changed over the course of the experiment was not determined. Also, the possibility that parts of the recorded responses to different salinity and temperature treatments are due to responses in the food organisms (i.e. indirect response) cannot be ruled out. However, the result is the same if the cause is direct or indirect.

Field-based studies have been widely used to examine the relationships of foraminiferal distribution patterns and various environmental parameters (reviewed by Murray 2006), and results serve as the basis for interpreting many paleoenvironments. The results of such studies rely on demonstrating a relationship, or at least a correlation, between observed foraminiferal distributions and trends in various environmental parameters. Coastal, shallow-water systems, however, are environmentally variable over short spatial and temporal scales, and results therefore have not always been conclusive (e.g. Geslin et al. 2000). Characterizing relationships between foraminiferal occurrences and environmental parameters in these settings is therefore difficult. Results of the present study provide a better understanding of the temperature and salinity preferences of several key shallow-water species and thus build on the compilations of field-based studies by others (e.g. Murray 2006).

Haynesina germanica, the most frequently encountered species in our study, is common and broadly distributed in temperate coastal settings and is con- 
sidered one of the most opportunistic brackish foraminifera of southern England (Murray 2006, p. 81). Results of the present study support this and show that it grows quickly and is capable of reproducing from at least 12 to $\sim 22^{\circ} \mathrm{C}$. This species is reportedly among those foraminifera most tolerant to environmental pollutants and is therefore a potential bioindicator species in coastal pollution studies (Armynot du Châtelet et al. 2004).

Species of Psammophaga, distinctive for their ingestion of numerous sediment grains, are also widely distributed biogeographically, with known occurrences in shallow waters of the Arctic, Antarctic, and temperate latitudes of both the Atlantic and Pacific (Arnold 1982, Pawlowski \& Holzmann 2008, Pawlowski \& Majewski 2011). These foraminiferans are probably more common than published reports would indicate. The fragile test found in these species is destroyed when sediment samples are dried, a common practice in many distribution studies on foraminifera. We know very little about the ecology of Psammophaga spp., though results of our study suggest that the Sapelo species is also a broadly adapted opportunist.

Four of the 6 dominant species retrieved from the experimentally grown assemblages (Ammonia tepida, Miliammina fusca, Elphidium excavatum, Ovammina opaca) illustrate different responses to temperature and salinity, and these results should serve to improve our interpretations of environmental conditions and change. For example, the results suggest that rising temperatures at southeastern United States coastal sites would be reflected in an increase in warm-adapted species such as $A$. tepida and $M$. fusca, and a corresponding decrease in the cooladapted $E$. excavatum in foraminiferal communities. The opposite would be expected during colder periods. Previous field-based studies, however, linked the relative abundances of species of Ammonia (e.g. A. parkinsoniana or $A$. beccarii) and E. excavatum to hypoxia, anoxia (Sen Gupta et al. 1996), or some other form of environmental stress (Thomas et al. 2000). Here we show that temperature is also a critical factor in determining the relative abundances of these species. In the present study, M. fusca grew preferentially at the warmer temperature; however, populations from maritime Canada have been characterized previously as being adapted to the cold (Scott \& Medioli 1980). This suggests that $M$. fusca may actually be a morphospecies complex of cryptic species with different environmental adaptations. This view is supported by the finding that $M$. fusca populations from coastal Georgia are distinct from those from maritime Canada in terms of the small subunit rDNA gene (Habura et al. 2006, A. Habura pers. comm.).

Growing assemblages of foraminifera from their propagule banks under different, controlled environmental conditions, the 'propagule method' presented here, provides a better understanding of the environmental preferences of individual taxa and how foraminiferal communities might respond to changing environments. It also provides insight into the influences of abiotic factors such as temperature and salinity on the assembly of foraminiferal associations.

Acknowledgements. We thank the staff of the University of Georgia Marine Institute, Sapelo Island, for logistical support, and John Shields at the Center for Ultrastructural Research for assistance with the SEM images. We also thank the reviewers and B. W. Hayward and C. J. Duffield for useful comments on the manuscript. This study was funded in part by a National Science Foundation Grant OCE0850505 to S.T.G. This is Contribution Number 1008 from the University of Georgia Marine Institute, Sapelo Island, Georgia.

\section{LITERATURE CITED}

Alve E (1999) Colonization of new habitats by benthic foraminifera: a review. Earth Sci Rev 46:167-185

- Alve E, Goldstein ST (2002) Resting stage in benthic foraminiferal propagules: a key feature for dispersal? Evidence from two shallow water species. J Micropalaeontol 21:95-96

- Alve E, Goldstein ST (2003) Propagule transport as a key method of dispersal in benthic foraminifera. Limnol Oceanogr 48:2163-2170

Alve E, Goldstein ST (2010) Dispersal, survival and delayed growth of benthic foraminiferal propagules. J Sea Res 63:36-51

> Armynot du Châtelet EA, Debenay JP, Soulard R (2004) Foraminiferal proxies for pollution monitoring in moderately polluted harbors. Environ Pollut 127:27-40

Arnold ZM (1955) Life history and cytology of the foraminiferan Allogromia laticollaris. Univ Calif Publ Zool 61: $167-252$

Arnold ZM (1982) Psammophaga simplora n. gen., n. sp., a polygenomic Californian saccamminid. J Foraminiferal Res 12:72-78

Austin HA, Austin WEN, Paterson DM (2005) Extracellular cracking and content removal of the benthic diatom Pleurosigma angulatum (Quekett) by the benthic foraminifera Haynesina germanica (Ehrenberg). Mar Micropaleontol 57:68-73

Bray JR, Curtis JT (1957) An ordination of the upland forest communities of southern Wisconsin. Ecol Monogr 27: 325-349

Buzas MA, Culver SJ (1994) Species pool and dynamics of marine paleocommunities. Science 264:1439-1441

Clarke KR, Gorley RN (2006) Primer v6: user manual/tutorial. Primer-E Ltd, Plymouth

Correia MJ, Lee JJ (2000) Chloroplast retention by Elphidium excavatum (Terquem). Is it a selective process? Sym- 
biosis 29:343-355

Dupuy C, Rossignol L, Geslin E, Pascal PY (2010) Predation of mudflat meio-macrofaunal metazoans by a calcareous foraminifer, Ammonia tepida (Cushman, 1926). J Foraminiferal Res 40:305-312

Fisher RA, Corbet AS, Williams CB (1943) The relationship between the number of species and the number of individuals in a random sample of an animal population. J Anim Ecol 12:42-58

Geslin E, Stouff V, Debenay JP, Lesourd M (2000) Environmental variation and foraminiferal test abnormalities. In: Martin RE (ed) Environmental micropaleontology: the application of microfossils to environmental geology. Kluwer, New York, NY, p 192-215

Goldstein ST (1999) Foraminifera: a biological overview. In: Sen Gupta BK (ed) Modern foraminifera. Kluwer, Dordrecht, p 37-55

Goldstein ST, Barker WW (1988) Test ultrastructure and taphonomy of the monothalamous agglutinated foraminifer Cribrothalammina, n. gen., alba (Heron-Allen and Earland). J Foraminiferal Res 18:130-136

Goldstein ST, Corliss BH (1994) Deposit feeding in selected deep-sea and shallow-water benthic foraminifera. DeepSea Res 41:229-241

Goldstein ST, Frey RW (1986) Salt marsh foraminifera, Sapelo Island, Georgia. Senckenb Marit 18:97-121

Goldstein ST, Harben EB (1993) Taphofacies implication of infaunal foraminiferal assemblages in a Georgia salt marsh, Sapelo Island. Micropaleontology 39:53-62

Habura A, Goldstein ST, Parfrey LW, Bowser SS (2006) Phylogeny and ultrastructure of Miliammina fusca: evidence for secondary loss of calcification in a miliolid foraminifer. J Eukaryot Microbiol 53:204-210

Hayward BW, Holzmann M, Grenfell HR, Pawlowski J, Triggs CM (2004) Morphological distinction of molecular types in Ammonia - towards a taxonomic revision of the world's most commonly misidentified foraminifera. Mar Micropaleontol 50:237-271

Heinz P, Geslin E, Hemleben C (2005) Laboratory observations of benthic foraminiferal cysts. Mar Biol Res 1: 149-159

Howard JD, Frey RW (1985) Physical and biogenic aspects of backbarrier sedimentary sequences, Georgia coast, USA. Mar Geol 63:77-127

> Jepps MW (1942) Studies on Polystomella Lamarck (Foraminifera). J Mar Biol Assoc UK 25:607-666

Knight R, Mantoura RFC (1985) Chlorophyll and carotenoid pigments in foraminifera and their symbiotic algae:

Editorial responsibility: Matthias Seaman, Oldendorf/Luhe, Germany analysis by high performance liquid chromatography. Mar Ecol Prog Ser 23:241-249

Leibold MA, Holyoak M, Mouquet N, Amarasekare P and others (2004) The metacommunity concept: a framework for multi-scale community ecology. Ecol Lett 7:601-613

Lopez E (1979) Algal chloroplasts in the protoplasm of three species of benthic foraminifera: taxonomic affinity, viability and persistence. Mar Biol 53:201-211

> Mojtahid M, Zubkov MV, Hartmann M, Gooday AJ (2011) Grazing of intertidal benthic foraminifera on bacteria: assessment using pulse-chase radiotracing. J Exp Mar Biol Ecol 399:25-34

Murray JW (2006) Ecology and applications of benthic foraminifera. Cambridge University Press, Cambridge

> Olsgard F (1999) Effects of copper contamination on recolonisation of subtidal marine soft sediments-an experimental field study. Mar Pollut Bull 38:448-462

Pascal PY, Dupuy C, Richard P, Niquil N (2008) Bacterivory in the common foraminifer Ammonia tepida: isotope tracer experiment and the controlling factors. J Exp Mar Biol Ecol 359:55-61

Pawlowski J, Holzmann M (2008) Diversity and geographic distribution of benthic foraminifera: a molecular perspective. Biodivers Conserv 17:317-328

Pawlowski J, Majewski W (2011) Magnetite-bearing foraminifera from Admiralty Bay, west Antarctica, with description of Psammophaga magentica, sp. nov. J Foraminiferal Res 41:3-13

Scott DB, Medioli FS (1980) Quantitative studies of marsh foraminiferal distribution in Nova Scotia: implications for sealevel studies. Cushman Found Foraminifera Res Spec Publ 17:1-58

Sen Gupta BK, Kilbourne RT (1976) Depth distribution of benthic foraminifera. In: First International Symposium on Benthonic Foraminifera of Continental Margins, Part A. Marit Sediments (Spec Publ) 1:25-38

Sen Gupta BK, Turner RE, Rabalais NN (1996) Seasonal oxygen depletion in continental-shelf waters of Louisiana: historical record of benthic foraminifers. Geology 24: $227-230$

Talge HK, Hallock P (2003) Ultrastructural responses in field-bleached and experimentally stressed Amphistegina gibbosa (Class Foraminifera). J Eukaryot Microbiol 50:324-333

Thomas E, Gapotchenko T, Varekamp JC, Mecray EL, Buchholtz ten Brink MR (2000) Benthic foraminifera and environmental changes in Long Island Sound. J Coast Res 16:641-655

Submitted: March 29, 2011; Accepted: August 14, 2011 Proofs received from author(s): August 30, 2011 